\title{
Vitrification of Hazardous and Radioactive Wastes (U)
}

by

D. F. Bickford

Westinghouse Savannah River Company

Savannah River Site

Aiken, South Carolina 29808

R. Schumacher

Westinghouse Savannah River Company

SC USA

A document prepared for FALL MEETING AMERICAN CERAMIC SOCIETY at Columbus from 11/14/94 $11 / 18 / 94$.

DOE Contract No. DE-AC09-89SR1 8035

This paper was prepared in connection with work done under the above contract number with the U.S.

Department of Energy. By acceptance of this paper, the publisher and/or recipient acknowledges the U.S. Government's right to retain a nonexclusive, royalty-free license in and to any copyright covering this paper, along with the right to reproduce and to authorize others to reproduce all or part of the copyrighted paper. 


\section{DISCLAIMER}

This report was prepared as an account of work sponsored by an agency of the United States Government. Neither the United States Government nor any agency thereof, nor any of their employees, makes any warranty, express or implied, or assumes any legal liability or responsibility for the accuracy, completeness, or usefulness of any information, apparatus, product, or process disclosed, or represents that its use would not infringe privately owned rights. Reference herein to any specific commercial product, process, or service by trade name, trademark, manufacturer, or otherwise does not necessarily constitute or imply its endorsement, recommendation, or favoring by the United States Government or any agency thereof. The views and opinions of authors expressed herein do not necessarily state or reflect those of the United States Government or any agency thereof.

This report has been reproduced directly from the best available copy.

Available to DOE and DOE contractors from the Office of Scientific and Technical Information, P.O. Box 62, Oak Ridge, TN 37831; prices available from (615) 576-8401.

Available to the public from the National Technical Information Service, U.S. Department of Commerce, 5285 Port Royal Road, Springfield, VA 22161. 


\section{DISCLAIMER}

Portions of this document may be illegible in electronic image products. Images are produced from the best available original document. 
VITRIFICATION OF HAZARDOUS AND RADIOACTIVE WASTES (u)

Dennis F. Bickford, and Ray Schumacher

Westinghouse Savannah River Co., Savannah River Technology Center, Aiken, SC 29808.

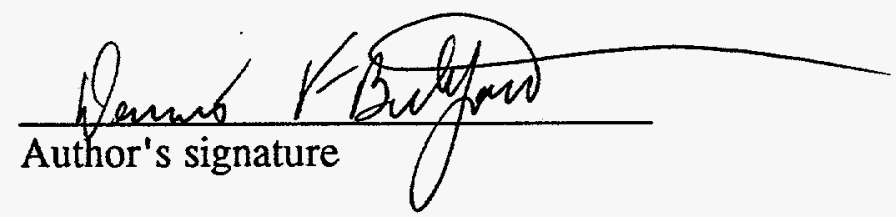

Derivitive Classifier's Signature

The information containedgin this paper was developed during the course of work under contract No. DE-AC09-8\$SR18035 with the US. Department of Energy. By acceptance of this paper, the publisher and/or recipient acknowledges the U.S. Govenment's right to retain a non-exclusive, royalty free license in and to any copyright covering this paper, along with the right to reproduce and to authorize others to reproduce all or part of the copyrighted paper. 


\title{
VITRIFICATION OF HAZARDOUS AND RADIOACTIVE WASTES
}

\author{
Dennis F. Bickford and Ray Schumacher \\ Westinghouse Savannah River Co. \\ Savannah River Technology Center \\ Aiken, SC 29808
}

Vitrification is cost effective and can produce an extremely durable glass form, which can isolate contaminants from the environment for thousands of years. Waste glass has been shown to be so stable that some vitrified wastes, such as municipal incinerator ash, can be made into consumer products such as ceramic tile, building materials or insulation. Benefits of the application of glass technology to the disposal of wastes include:

well characterized waste form stability, extremely low release rates in environmental conditions, excellent mechanical and thermal stability, no combustible or pyrophoric properties, retention of essential release properties even if disturbed or mechanically damaged during storage or disposal, low generation of potentially respirable particles, ability to accept high loadings of heavy metals, ability to accommodate fluctuating waste types with negligable effect on release properties,

ability to combust limited amounts of organics (including carcinogens),

volume reduction, reducing disposal costs

total destruction of asbestos,

and scale of facility adaptable to accommodate a wide range of disposal needs.

Compliance with environmental waste disposal regulations can be very expensive. While vitrification capital costs may be somewhat higher than conventional waste solidification techniques, such as cementation, the expense is more than offset by the savings from volume reduction and reduced monitoring inherent in the more durable waste form. The high temperature in the melter also destroys organic materials, thus further reducing the regulatory burden of disposal.

In the last decade there has been increased commercial interest in waste vitrification, and a growing convergence of the traditional commercial glassmaking and metallurgical approaches to waste glass production. The metallurgical approach is characterized by extremely high operating temperatures with molten metals present, strongly reducing conditions, and products that are not dependent on variations in appearance or small volume defects. In the metallurgical tradition, the glassy phase 
(silicious slag, or sulfurous matte) is a waste byproduct which should be minimized, and which results from winning metals from ores, or in secondary smelting operations. In a number of commercially successful operations the slags are tailored to also meet end-use requirements, such as fiberizing into thermal insulation, as aggregate in concrete or asphalt construction, or as specialty industrial or agricultural products (basic slag replacing agricultural limestone, or as a source of micronutrients). These product lines have generally grown out of efforts to market value added products that would otherwise be wastes which would require landfilling, thus avoiding the costs, permits and liabilities that are normally associated with landfills or toxic waste dumps: e.g., phosphorous in a slag going to a land fill incurs an expense for carting and disposal and remains a source of potential liability concern because of possible ground water contamination - The same phosphorous as a product leaving a fertilizer plant is a major desireable constituent, that has a commercial market.

In the metallurgical tradition many of the refractories used are basic and are incompatible with production of high durability glasses. For example, a basic oxygen furnace for iron production may have a slag that is saturated with lime to maximize the scavenging of sulfur and phosphorous. A refractory of CaO may function for two years in this service, but would be dissolved in one week's time if subjected to a soda-lime-silicate bottle glass at the same temperature. By comparison, commercial glasses are usually acidic melts, and efforts to minimize furnace rebuilding result in the use of durable, acidic refractories: silica, high alumina, high zirconia, or high chromium oxide refractories, which are generally not compatible with a molten metal phase.

Electric Arc Furnace Dust A recent application in the metallurgical market has been commerical projects to recover value from offgas scrubbing products and offgas filtrates. Electric arc furnace dust is an EPA listed hazardous waste because of its tendency to accumulate toxic semivolatile metals and anions $(\mathrm{Pb}, \mathrm{Cd}, \mathrm{Cr}, \mathrm{As}, \mathrm{F}, \mathrm{Cl}, \mathrm{SOX})$. Horsehead Resource Dev. Co. reports the ability to process 500,000 tons per year of zincbearing wastes, and 80,000 tons per year of $z$ inc and lead from electric arc furnace dusts, including flash smelting processes. Wastes treated include sludges from electroplating, foundary, and secondary smelting industries. Oregon steel Mills reports production of 30,000 tons per year of glass from bag house dust, spent refractories, slags, and other steel mill byproducts. Inorganic Recycling Co. reports an EPA recognized, RCRA exempt, recycling system for vitrificaton of sludges and filter cake from plating operations, municipal incinerator ash, electric arc furnace dust, contaminated soils and industrial ashes. Ceramics produced include architectural, abrasive, and refractory 
products. Enviroscience, Inc. reports recovery of $\mathrm{Zn}, \mathrm{Cd}$, and $\mathrm{Pb}$ while producing insulating fiber from spent aluminum potliners and electric arc furnace dust.

Municipal Waste Incinerator Ash Similar to the electric arc furnace dust is the ash from municipal waste incinerators. In Japan and Europe these ashes are regulated as hazardous waste, requiring treatment before disposal. In the'U.S. the municipal ashes have been specifically exempted from regulation, but recent court findings have attacked the concept that wastes are exempt because of the source of the waste. Thus, we can expect increased interest in vitrification, particularly with recovery of metals and the production of a saleable product. The U.S. Bureau of Mines and the American Society of Mechanical Engineers through cooperative agreements with over 30 government and industrial sponsers conducted melting tests of ash from 5 municipal incinerators, includinğ sewage sludge combúster ash. Production rate was 1500 pounds per hour. An economic evaluation of the operation is available from the Bureau of Mines. The glass product passed the U.S. Environmental Protection Ageny's Toxic Characteristic Leaching Procedure (EPA TCLP) testing, and ASTM requirements for aggregate in portland cement or asphaltic concretes. Battelle Pacific Northwest Laboratory has concluded that vitrification of municipal ash costs about $\$ 53$ per ton, with vitrification saving $\$ 25$ per ton versus cartage and disposal for an evaluated site.

In the glass making tradition, the glass product and its forming or final characteristics are the reason for the glass making operation. Thus, glass product formulation is rigidly controlled, with raw materials selected for their uniformity in composition and physical or handling characteristics. The incorporation of regulated waste products into such operations are difficult because of the inherent variations in source material. This additional process variation, and the increased regulatory requirements have minimized use of waste materials that are not produced internally. However, recycling, environmental and litter control regulations are increasing the use of internally-generated and post-consumer recycle in the glass bottling and television/computer monitor production plants.

\section{RADIOACTIVE WASTE TREATMENT}

It is important to make the best use of the available technology to aid in the safe and efficient disposal of wastes at the U.S. Department of Energy (DOE) sites. A relatively mature technology, waste vitrification has been found to be cost effective, environmentally sound, and well suited for a variety of radioactive waste types. Scientists began studying the technique of incorporating radioactive waste into glass during 
the 1950's. Experimental melters have been used since 1975 to perfect the vitrification process. Over the past 20 years, scientists and engineers at the U.S. Department of Energy's Savannah River, and Hanford sites, and at the West Valley Demonstration Project have been developing expertise to characterize waste, tailored formulations to produce durable waste glasses, and developed technologies to effectively process and vitrify these wastes. Recently the glass melter in the Defense Waste Processing Facility (DWPF) was started up at the Savannh River Site (SRS). This facility is designed to remotely process and vitrify the high-level radioactive waste currently stored at the SRS. Startup of the melter was a vital part of the facility qualification, and involved treatment of simulated waste. The qualification phase will continue until late 1995 when radioactive wastes are scheduled to be processed in the facility.

The Environmental Protection Agency has declared vitrification the "best demonstrated available technology " (BDAT) for stabilization of heavy metals and high level radioactive waste. Nine nations have either chosen, or are considering, glass as a solid waste form for their highly radioactive wastes. By choosing glasss, they minimize the lengthy, costly testing required of other waste forms. In a recent federal facilities compliance agreement between the EPA, the state of Washington, and the DOE, the DOE agreed to vitrify both the High Level Waste and the Low Level Radioactive Waste resulting from processing of Tank Waste stored at the Hanford Site. This is expected to result in the requirement of 100 ton per day Low Level Radioactive Waste melters, and a high level waste vitrification facility with about four times the production capacity of the DWPF. Thus, there is increased need for the rapid adaptation of commercial melter equipment to DOE's needs.

The Mixed Waste Intregrated Program seeks to develop and demonstrate technologies which can make significant improvement on existing commercially mature treatment systems. Vitrification has the potential to treat approximately 75\% of the mixed (RCRA hazardous and radioactive) wastes being stored at DOE sites. The waste glass systems that are being considered are soda-limesilica, borosilicate, aluminosilicate, nepheline, basalt, iron enriched basalt and phosphate glass systems. Glass ceramic systems have also been considered, many of which can be potentially produced as glass and subsequently heat treated to develop crystalline phases. Efforts are underway at SRS, Hanford, INEL, and the Rocky Flats Plant to develop vitrification technologies for low-level mixed (radioactive and hazardous) waste sludges, incinerator ashes, ion-exchange resins, contaminated soils, asbestos, solutions of actinide elements (Pu, $\mathrm{Np}, \mathrm{Am}, \mathrm{Cm})$, heterogeneous radioactive metal, and organic wastes. 
A transportable "Modular Melter System" is being procured by SRS for field demonstrations of vitrification at various DOE sites on contact handled wastes. The Modular system will have generic melter feed, offgas treatment and laboratory capacity. Alternative melter systems can be substituted for the original melter after initial operations, to handle variations in physical or chemical properties of the wastes. The entire system can be transported via tractor trailers to allow vitrification of a variety of hazardous waste streams at different sites.

The ability to vitrify waste depends upon how well the waste is characterized, and on the flexibility of the melter and of the glass formulation. Considerations are physical form of the waste, size, water and organic contents, handling characteristics, ash compostion, volatile materials, and extent of remote handling required. Relatively minor mass fractions of radioactive materials can cause orders of magnitude differences in the cost of personnel protection, offgas treatment required, and the capital, operational and maintenance costs. Waste is characterized using the most advanced technologies available, and the best way to vitrify the waste products is determined. Hazardous species in almost any material can be characterized using tools that include inductively coupled plasma-atomic emmision spectroscopy; inductively coupled plasma-mass spectroscopy; atomic absorbtion spectroscopy, ion chromatography; $x$-ray diffraction; and $x$-ray fluorescense. For radioactive elements, gamma ray spectroscopy and alpha energy spectroscopy may be combined with more traditional counting methods.

The behavior of nearly every element in the periodic table has been studied in waste glass development. SRS has used a systems approach and process models have been developed to ensure that the melt's viscosity, durability, liquidus, and other important properties can be estimated from the the melter feed ingredients. For more compelx problems, the product composition control system, built upon proprietary statistical process control algorithms, allows for random variations, and suggests corrective actions. As a result, a durable glass product is reliably produced, while minimizing process upsets.

DOE has needed a facility where commercial pilot scale equipment could be operated on surrogate (non-radioactive) simulations of typical DOE waste streams. The DOE/Industry Center for Vitrification Research (Center) was established in 1992 at the Clemson University Department of Environmental systems Engineering, Clemson, SC, to address that need. The center aids in the application of vitrification technology to the immobilization of hazardous, radioactive, and mixed wastes, by combining technology and lessons learned in commercial glass 
making with DOE contractor experience and DOE needs. During surrogate operations the melters are checked for:

1) general operability (i.e. does the unit perform as advertised)

2) general limits of processability (e.g. operating temperature range),

3) normal and specialized maintenance requirements,

4) compatibility with waste glass formulations (i.e. materials of construction, since high temperature equipment can be rapidly destroyed by chemical attack if materials of construction are not suitable)

5) interfaces with the rest of the treatment system (pretreatment and offgas treatment requirements),

6) product conformance to regulatory requirements, and

7) as far as possible the operating economics (life cycle costs, manpower requirements, utilities, raw material costs).

\section{RADIOACTIVE WASTE TYPES SUITABLE FOR VITRIFICATION}

Melters are being applied to the immobilization, volume reduction and stabilization of High Level Radioactive Waste (HLW) Low Level Mixed Wastes (LLMW), Transuranic (TRU), Pu238 (alpha), Low Level, and chemical (RCRA) wastes. LLMW and TRU types generally do not require heavy shielding to control radiation doses to operating and maintenance personnel. The low penetrating radiation levels of these wastes allow them to be treated in facilities where direct contact maintenance can obviate the expense of remote maintenance facilities. Direct contact maintenance allows the adaptation of commercially available equipment, which has been precluded by the restricted maintenance conditions in High Level Waste facilities. Thus, rather than using expensive custom melter designs, the LLMW and TRU processes can potentially use adaptations of commercial glass making equipment. However, these wastes share many contamination and environmental release concerns with High Level Waste. Thus, they require waste-form quality, contamination control features, and production control practices similar to the High-Level Wastes. When treating LLMW the requirements for protection of the operating personnel from contact with the wastes vary dramatically, dependent upon the source and type of the waste. For example, the hazards associated with natural and low enrichment uranium are primarily those of potential heavy metal poisoning. In contrast, the $10-$ 100 nanocurie per gram low level transuranic wastes are potential sources of ingestion of maximum permissible body burden dosages of plutonium, since they may contain small "hot spots" or particles which could become airbourne and result in personnel contamination through ingestion or respiration. 
Vitrification has been demonstrated to be capable of incinerating organic materials and incorporating the resulting ashes in a number of inorganic glass systems. Initial operations have focussed on the vitrification and volume reduction of inorganic sludges resulting from waste water treatment. Parallel efforts under the Minimum Additive Waste Stabilization Program (MAWS), the Buried Waste Integated Program (BWIP) and at other DOE sites are developing treatment of soils and wastes with high metallic content.

Low Level, $\beta-\gamma$ wastes are generally disposed of as cement waste forms, or by burial, because their hazards are similar to those of the uranium ore these wastes originally came from. These wastes result primarily from uranium operations which produce reactor fuel, and targets for plutonium production. At this time, the additional expense of general vitrification relative to cement stabilization is justifiable for simple hazardous or LLW where the volume reduction of the vitrification process can reduce the life cycle disposal cost, or where site specific conditions require the high durability of glass waste forms.

If the Low Level wastes are contaminated with transuranic (TRU) isotopes, have unusually high activities, or contain hazardous chemicals converting them to Mixed Wastes, then the added stability and leach resistance of vitreous waste forms is very desireable, and is generally economically justifiable when transportation and final disposal costs are considered. This should be practical through the adaptation of standardized melter designs, and mineral based raw materials, as practiced by the commercial glass industry.

Mixed wastes, heavy metals, inorganics, asbestos, and organic wastes share many of the characteristics of $\beta-\gamma$ wastes, but they contain RCRA listed chemical elements or compounds which require permanent isolation from the environment. The high temperature melting process destroys the chemical compounds associated with such wastes, and ties poisonous elements up into a durable matrix. It has been demonstrated that soda-lime-silicate, alluminosilicate, and borosilicate glasses bind hazardous elements. Current wastes of the $\beta-\gamma$ type that are most suitable for vitrification are SRS M Area sludges and filter papers resulting from uranium forming and cladding, and similar waste water treatment sludges from Oak Ridge, Rocky Flats Plant and Los Alamos Scientific Laboratory. The M Area sludges have been contracted for on-site vitrification treatment by Duratek Co. There is enough inventory to keep a large scale facility operating for about two years, after which the equipment will be available for treatment of other wastes. A model "Upfront" delisting petition is being prepared for SRS M-Area sludge so that these wastes can be delisted from RCRA concern, allowing 
them to be disposed as Low Level Waste. Again, economics plays a major role in the effective disposal of these wastes, the major justification being that delisting of the hazardous portion of these wastes will allow more efficient disposal. Vitrification is clearly justified for these wastes because it will reduce the waste volume relative to the cement waste form, and will provide an increase in waste form durability: In fact, the vitrification process won over a competitive cementation process for the M Area sludge treatment because it was able to demonstrate lower disposal volumes and costs.

A large fraction of the wastes falling in the LLMW and DOE'S Intermediate Level waste category $(<300 \mathrm{mR} / \mathrm{hr})$ originate in TRU and HLW facilities, justifying greater leach resistance than those containing only natural or depleted uranium.

In the future, the Consolidated Incinerator Facility (CIF) will produce ash, and offgas filtration residues (blowdown) that will need to be immobilized and stored. Since many of the wastes to be processed in the CIF originate in HLW and TRU facilities, the ashes of the CIF will contain some levels of alpha emmitters, and HLW residues. Current plans are to add cement to bottom ash drums and store the solidified ash in vaults. Vitrification, with and without waste water treatment, is being investigated for treatment of the blowdown, which has a high salt content.

$\alpha$ emitting transuranic wastes (TRU) are comparable to High Level Waste in biologic risk, but require smaller scale operations. In these waste types, major goals are to convert small volumes of liquid or solid flammable wastes into small waste forms that are easy to handle, but provide a high degree of contamination control (isolation). Waste glass is essentially a sealed source, which reduces the dispersibility of a wastes during accidents, and the transferability of activity by contact. The high temperature melting process combusts organics and reduces the volume of this waste catagory, which primarily consists of solutions, contaminated plastic, cloth and paper products. Current investigations at SRS include formulation of glasses for vitrifying surplus transuranic solutions. If the TRU solutions were declared waste, they would be considered mixed waste because of their low $\mathrm{pH}$ and high nitrate concentrations. Vitrification will allow the storage and subsequent shipment and use of $\mathrm{Pu}, \mathrm{Np}$, Am and $\mathrm{Cm}$.

Contaminated Soils Contamination can be the result of hazardous chemical spills, or low levels of TRU or mixed fission products. Currently, these wastes are disposed of without further processing by shallow land burial. Vitrification of these materials will bind the hazardous and radioactive species, reducing the risk of ground water contamination. 


\section{AVAILABLE MELTERS AND SYSTEMS}

The range of melter technologjes developed, or being developed includes Joule-heated melters, induction melters, high temperature plasma torch systems, resistively heated refractory metal bushings, and microwave systems. Each system has advantages for application to specific waste streams. Tailoring technologies to particular waste steams helps to maximize effectiveness and efficiency of waste vitrification options.

The Defense Waste Processing Facility (DWPF) at the U.S. Department of Energy's Savannah River Site has an anticipated operating life of over 18 years, using a remotely replaceable melter with a design life of 2 years. Similar equipment and facility development efforts are underway, or have been completed, for HLW disposal at the West Valley Demonstration Project (WVDP), Hanford Waste Vitrification Project (HWVP), and in France, Belgium, Germany, and Japan. As part of this process a number of melter systems of various capacities have been designed, constructed and operated. Most of these systems have been operated and maintained in non-radioactive and non-hazardous environments as part of equipment development and demonstrations. However, several large scale pilot and production units have been operated with hazardous melter feeds, radioactive spikes, or HLW. Design, construction and operation of these facilities provides a basis for the evaluation of the costs of volume reduction and immobilization of other wastes in similar facilities.

In-Can Melters (Pot Melters) Pot melters using refractory or platinum lined pots are standard commercial methods of melting low volumes of specialty glasses. In-can melters with calciners and slurry fed pot melters were constructed and operated at full scale by Hanford and SRS. The original concept for HLW glass melters was for batch operations, which was a direct increase in scale from crucible tests. This approach was found unsuitable for HLW production facilities because of slow melt rates caused by slow heat transfer from the external heaters through the canister into the reacting batch. Lack of agitation and temperature nonuniformities also made it difficult to homogenize the glass. While calcination of feed before introduction into the canister increased the melt rate, it also increased the tendency for crystal formation in the glass, and entrained waste in the calciner offgas system. The second group of radioactive waste melters developed were continuous pot melters. In this type the melt rate was increased by increasing the diameter of the pot, by direct heating of the pot using radio frequency induction heating, and by continuous feeding of raw materials. Glass homogeneity was improved by using gas bubblers to agitate the melt. The largest melter of this type operating is the French $A V H$ 
system which melts 55 pounds per hour. This is the processing rate limit per pot melter using dried feed: however, with slurry feeding the melter capacity limit would be about one half of this, or $27 \mathrm{pph}$ per melter. The melter design temperature is limited to about $1150^{\circ} \mathrm{C}$ by creep resistance of the Inconel (TM) alloy used for the pot. This method was finally eliminated for U.S. HLW based on the large number of melters, calciners and offgas systems (operating in parallel) that would be required to meet the production rates required to dispose of DOE waste inventories. These systems are considered practical for relatively low volume wastes, have simplified maintenance, are easily connected between equipment, and have a relatively low capital investment if remotely maintained facilities are not required. Facility cost is dependent upon the hazard of the waste being processed, and can vary between weatherproof sheds to large, remote manipulator cells. The capacity limitations of these systems eliminate them from general consideration, but they remain suitable for small scale operations with LLMW, TRU, and HLW.

Similar to the continuous pot melters are the commercially available bushing melters which are used to melt high quality fiber glass. Pots for these systems are fabricated from platinum group metals, and are heated by passing current through the pot. The commercial systems are economically viable because of very low consumption rates of the platinum, and the ability to recover the platinum for reuse. SRS is considering small systems based on commercial bushings for speciallized TRU melting.

Slurry Fed Melters (SFM), also known as HLW melters, Joule Heated Melters, and Ceramic Melters, have been developed in the U.S., Europe and Japan for the conversion of HLW to borosilicate glass for permanent disposal. Laboratory and pilot scale operations have been conducted to develop equipment, glass compositions and control methods. The majority of these systems have been developed for remote operation, with essentially no maintenance over a 2 to 4 year melter life. The relatively high cost of these melters is the result of the specialized requirements of remote installation, operation, maintenance and removal. The systems were developed for vitrification of waste water treatment sludges, and are very suitable for that operation, but the largest existing design (SRS: DWPF). is limited to about 500 pounds per hour of glass when fed dry feed. Glass composition, melt rate, waste loading and glass quality are limited by the maximum operating temperature of about $1150^{\circ} \mathrm{C}$, resulting from the use of Inconel 690 (TM) electrodes and heaters. Several HLW melters have been operated continuously for over 4 years without requiring repairs. 
The slurry fed melters are the result of several generations of melter development based originally on commercial, electrically heated melters, adapted to the requirements of remote, noncontact maintenance, where the only available tools for changing out melter components or entire melters are a crane with hooks and an impact wrench. Major differences between HLW Melters and Commercial Melters have been: the use of metal shells to contain glass contact refractories and thermal insulation, the development of specialized slurry feeding and glass pouring systems, and the use of nickel based alloys for electrodes carefully matched with glass composition control.

Microwave pot melter Microwave heated sytems are being investigated at the Rocky Flats Plant and at ORNL for treatment of sludges and salts. The RF and ORNL systems use direct microwave heating of the waste, eliminating the need for electrodes in the molten glass. SRS is conducting research at the University of Florida on hybrid sytems, where silicon carbide susceptors provide the microwave coupling required to establish and stabilize the heating. The microwave systems have many of the throughput limitations of the other pot melter systems. systems which use metal cans as the heating cavity have the glass quality and the waste loading limited by the melting point of the pot. Localized hot spots resulting from nonuniform absorbtion of microwave energy can cause damage to the pot. Metals contained in the waste can result in arcing, which can also damage the pots. Large scale equipment requires tuning systems to maintain coupling at the surface of the melt, reduce the risks to the pot and decrease variations in wasteform quality which can result from nonuniform energy absorbtion. Laboratory scale equipment for crucible testing is very inexpensive, and units have been modified for remote use. Several laboratory scale systems are available at SRS and the University of Florida. HLW analytical samples are typically fused in microwave systems because they permit rapid heating, and only the interior of the chamber becomes hot.

Induction melters have been used for about 40 years at the SRS for production melting of uranium, lithium, plutonium and aluminum alloys, for vacuum hot pressing of plutonium dioxide, and to initiate transuranic fluoride reductions. They are reliable, low cost, high throughput devices for the melting of metals which directly couple to the radio frequency fields established by the induction coils, or the material to be melted can be indirectly heated by RF coupling to the graphite or silicon carbide crucible. The metal melting systems have used graphite and silicon carbide crucibles, with magnetic stirring to assure alloy uniformity. 
The Scientific Ecology Group (SEG) has a commercial low level waste operation at Oak Ridge, TN, where contaminated steels are remelted and cast into reactor shielding blocks. The majority of the non-activation product contamination is removed and goes into the glass during the operation. Similar decontamination has been seen in induction melting of stainless steel reactor fuel hulls in France. Reactive metals, such as zirconium are not decontaminated during remelting, because the zirconium is a powerful reducing agent, causing the radioactive species to be chemically reduced and alloyed with the remelted metal.

Cold Crucible Induction Melters Melter manufacturers in France, Russia and the United States, have developed cold crucible induction melters, where the water cooled induction coil is in direct contact with the material being melted. The steep temperature gradients produced adjacent to the induction coil cause a "skull" melting effect, where the material being produced forms its own crucible. In waste melter operations this means that the need for replacement of crucible materials is avoided, at the cost of reduced melting rate. Through the use of high frequency induction, there is direct RF coupling to waste glass, as a means of achieving high glass melter temperatures without the use of electrodes.

Advanced Gas Melter systems are being developed to provide compact units with high melt rates and minimum operating costs. Similar systems have been investigated as waste incinerators. The systems are based on intimate mixing of the waste and glass forming materials with the fossil fuel providing the operating temperature. The systems have been operated on dry, slurried, and liquid waste streams, and have demonstarted high melt rates. The maximum particle size of materials to be melted is approximately $2 \mathrm{~mm}$, making them more suitable for finely divided sludges and soils than for coarse soils, concrete or debris. Demonstrations are needed to determine the volatility of high vapor pressure metals and the physical entrainment and separation of high specific activity materials such as plutonium and cesium, and to determine the need for further homogenization.

High Temperature Melters are based on commercial melter materials which permit operation at temperatures higher than those of the HLW systems. The commercial systems are also based on direct contact maintenance, allowing possible cost reductions for LLMW treatment. As in all high temperature systems, the life of the system, and a large fraction of the cost is limited by the materials of construction. Glass systems include borosilicate, aluminosilicate, calcia-aluminosilicate, basalt, and soda-limesilicate systems. As a result of the broad range of glass compositions and refractory and electrode materials available, a major need for commercial waste glass systems is selection of 
compositon limits, operating temperatures and materials of construction: For optimum operations these can vary from one waste to the next. A second major need in commercial glass systems is sealing of the systems to control airborne contamination during the melter feeding and glass pouring operations and demonstration of slurry feeding of wet sludges. Battelle Pacific Northwest Lab., Clemson University and SRS are investigating these systems.

Stirred Melter The current stirred-melter was developed to combine the high production rates and high glass quality features of the Joule-heated melters with the low-cost, compact, easily maintained features of the pot melters. Melt rates in the stirred-melter are believed to be proportional to melter volume, rather than melt surface area as in conventional melters. Melters are being developed by Stir-Melter, Inc, and Clemson University.

Graphite Electrode Arc Melters are the basis for stainless steel and ferro alloy production, as well as such diverse operations as acetylene, phosphate, and fuse-cast refractory production (zirconia, alumina and chromia). Commercial units can be as large as 50 feet in diameter with electrodes in excess of 2 meters in diameter. The electrodes for such systems require constant renewal, since the graphite reacts with the melt and with oxygen in the melter atmosphere. Methods are available for electrode feeding, including forming and graphitization of the electrodes as they are consummed. Many melters are run "cold top" in open crucibles, where the feed batch provides the furnace cover. Refractories are selected based on the chemical system being processed, and refractory life varies dramatically dependent upon product and the amount of thermal cycling. Most of these systems operate in foundry environments, and have not required sealing of the electrodes to the furnace, or fume control during pouring. As a result, most commercial melter systems have uncontrolled air leakage around electrodes, and do not provide sufficient fume control or prevent contamination of the outside of the vessel. Combustible gasses can be formed by carbothermic reaction, pyrolysis of the treated material or by water-gas-shift reactions between carbon and water. The most extensive research of graphite electrode arc systems for DOE wastes have been conducted by INEL, and by PNL at the Massachusetts Institute of Technology (MIT). MIT tests have focussed on hollow graphite electrodes, allowing the production of coaxial electrodes and the passing of waste materials directly through the plasma, via their addition or exhaust through the hollow electrode. PNL is also developing large scale melters for soil treatment. Demonstrations of refractory life, control of melter pouring, control of wasteglass quality, control of combustible offgasses, and control of high vapor pressure metals 
are required. Bench scale systems have been built and operated sucessfully by INEL that include applied glass quality and offgas characterization.

Plasma Arc Melting can be non-transferred or transferred. In the non-transferred arc mode, the plasma torch operates as a very intense heater, with heat transfer occuring via impingement of the arc, or by thermal radiation. In the transferred arc mode, the material being heated forms one of the electrodes, assuring direct heating by the arc, with the possibility of joule heating within the treated material. Furnaces may be refractory lined, or of the cold crucible type. Refractory lined systems must have control limits to minimize glass and metal attack, and overheating by the plasma. Plasma arc torch design is a mature technology, and is available from a number of vendors, but torches require rebuilding on a monthly basis. Torch failure can result in uncontrolled coolant addition to the treatment furnace. Treatment furnaces have been offered commercially, but except for primary metals production they have been used primarily for recyle of metals or laboratory testing. Systems for tapping and assuring good separation of the metal / glass are under development by Scientific Applications International Co. and Argonne National Lab. A rotary hearth treatment unit is available from Retech Co. A portable plasma cupola system is available from Westinghouse Electric Co. The Georgia Institute of Technology has been funded by the Department of Defense to develop systems for vitrification of contaminated asbestos wastes.

Demonstrations of refractory life, control of melter pouring, control of wasteglass quality, control of combustible offgasses, control of high vapor pressure metals, control of volatilization and entrainment of radioactive materials, integration to offgas systems, and maintenance of the torch under radioactive conditions are required. The non-transfered arc systems are perceived to have superior arc stability and perhaps lower offgas entrainment than the transferred arc systems. The transferred arc systems are expected to be more efficient in maintaining melt pools at temperature, but may require more complicated power and operating systems to assure arc stability and avoid refractory overheating. 
SUMMARY

Vitrification offers many attractive waste stabilization options. Versatility of waste compositions, as well as the inherent durability of a glass waste form, have made vitrification the treatment of choice for high-level radioactive wastes. Adapting the technology to other hazardous and radioactive waste streams will provide an evironmentally acceptable solution to many of the waste challenges that face the public today.

\section{ACKNOWLEDGEMENT}

This work was conducted under Contract No. DE-AC09-88SR18035 with the U.S. Dept of Energy, under the Office of Technology Development's Mixed Waste Integrated Program.

\section{REFERENCES}

D. William Tedder, ed., "Emerging Technologies in Hazardous Waste Management", Abstracts for Special Symposium, Atlanta Ga, Sept. 1993, American Chemical Society, 1080 pages.

U. S. Environmental Protection Agency, Burning of Hazardous Waste in Boilers and Industrial Furnaces, Final Rule, Government Printing office, Washington DC, 1991.

C. C. Chapman, "Evaluation of Vitrifying Municipal Incinerator Ash", G.G. Wicks, D.F. Bickford and L.R. Bunnell, eds., Nuclear Waste Management IV, Ceramic Transactions vol. 23, American Ceramic Society, 1991, pp 223-231.

A.K. Varshneya, D.F. Bickford, and P.B. Bihuniak, eds., Advances in Fusion and Processing of Glass, Ceramic Transactions vol. 29, American Ceramic Society, 1993, 663 pages.

C.W. Frank, J.L. Steele, et al, eds., Proceedings Nuclear and Hazardous Waste Management: SPECTRUM 194, August 1418 1994, Atlanta GA, American Nuclear Society, 1994, 2455 pages. 